\title{
Performance Information Use: The Impact of Perceived Stakeholder Salience
}

\author{
Germaine Chan \\ Mount Saint Vincent University
}

\begin{abstract}
Stakeholders often hold divergent, and sometimes, adversarial views on organizational initiatives. Performance management in the higher education sector is no exception. Thus, which stakeholders will have their preferences met? Will it be the most important stakeholders? This study measures university leaders' perceived salience of three stakeholder groups - academics, staff, students - and the impact it has on performance management, specifically the use of performance information to inform the decisionmaking process. Results show that although staff is perceived to be the least salient, they are the only stakeholder group to have an influence on performance information use.
\end{abstract}

Keywords: performance information use, performance management in higher education, faculty salience, stakeholder salience and performance information use, performance management

\section{INTRODUCTION}

Despite controversy and resistance surrounding performance management (PM) these systems are increasingly commonplace in the public sector (Pollitt, 2006; Speckle \& Verbeeten, 2014). However, given the lack of a profit motive and the multi-mission nature of the sector how do public organizations know if PM systems are worth the cost and the effort? Scholars who have examined this question propose that one measure of success is the extent to which public sector managers use performance information (PI) to inform the decision-making process (Moynihan \& Pandey, 2010; Van Dooren \& Wouter, 2008). As a result, in order to move the field closer to a theory of PI use several studies have been conducted to examine which variables predict PI use.

One variable found to influence PI use is stakeholder support for PM (Berman \& Wang, 2000; Boyne et al., 2004; Folz et al., 2009; Ho, 2006; Julnes \& Holzer 2001; Yang \& Hsieh, 2006). However, it is not unusual for stakeholders to have divergent, and even adversarial views, with respect to large-scale organizational initiatives such as PM. That is, stakeholders have preferences. Indeed, there have been numerous studies that have identified and examined different stakeholder preferences. For example, Yamane and Kaneko (2021) found that stakeholders had preferences for corporate behavior relating to sustainable development goals. Thompson and Friess (2019) investigated stakeholder preferences for the sustainable development and conservation of mangrove forests. Schito et al., (2019) identified stakeholder preferences for where power lines should be installed in communities.

Internal higher education stakeholder groups include students, academics, non-academic staff, herein called staff, senior administrators and board members. External groups include government funding bodies, donors, communities and taxpayers. However, not all stakeholder groups view PM in the same light. Much of the criticism surrounding PM is from academics, many of whom view PM an attempt to corporatize the 
academy and an infringement on academic rights and freedoms to name only a few (see Alvesson \& Spicer, 2016; Birdsall 2018; Craig et al., 2014; Kairuz et al., 2015; Kalfa et al., 2018; Kallio et al., 2016; Kenny, 2017). On the other hand, there are some academics that support PM (Chan, 2018). Students (or their parents), who are saddled with increasingly high tuition fees, tend to favor performance measures that lead to increased quality, efficiencies and reduced costs. For most students, the value of higher education is often translated into dollars and cents (Cain et al., 2012) and thus calculating the return on investment of a university education is becoming an increasingly commonplace exercise (see Ashford, 2014; Maple, 2013). Therefore, students welcome information about university programs including performance indicators related to graduation and job placement rates, academic programs, and social/ housing facilities. As well, many students refer to the many national and international rankings that measure various dimensions of university performance. Staff, in particular those who are unionized, tend to be unsupportive of PM initiatives (Julnes \& Holzer, 2001) because more efficiencies often translate into the elimination of jobs. However, higher education has hired an increasing level of non-unionized professional staff in managerial positions (Blau, 1973; Gordon \& Whitchurch, 2007; Schneijderberg \& Merkator, 2013). Some of these individuals may come from industry and thus may be accustomed to PM or they actually may be tasked with developing and implementing PM. Governments, who provide a significant but also decreasing portion of funding to the higher education, are pressuring universities to do more with less. Indeed, many governments are adopting performance-based budgeting that will tie significant amounts of funding to several performance measures (CAUT, 2020). Therefore governments that provide funding will support, and in some cases mandate, initiatives such as PM.

Given these divergent views on PM it is argued that some stakeholders may wish to minimize PM and PI use while others may want to incorporate it into as many organizational activities as possible. Thus, which stakeholder group will have its preferences satisfied? There have been many studies on the effect of powerful stakeholders on organizations (see Loi \& Pearce, 2012; Hart \& Sharma, 2004). However, there is scant research on the effect of perceived stakeholder salience on PI use. Therefore, the following research question fills this gap and makes a contribution to the theory of PI use by empirically examining the following research question: Do university leaders' perceptions of stakeholder salience influence the extent to which they use performance information?

\section{THEORETICAL FOUNDATION}

\section{Theory of Evidence-Based Decision-Making}

The conceptual theory of evidence-based decision-making, by Baba and HakemZadeh (2012), provides support for the argument that stakeholder preferences influence whether evidence, a form of PI, is used for decision-making purposes. The theory, presented in Figure 1, proposes that the type of evidence used is a factor of an individual's education, experience and judgement. Whether the evidence makes it way to the final decision is influenced by both managerial and stakeholder preferences along with context and ethical constraints.

\section{FIGURE 1 THEORY OF EVIDENCE- BASED DECISION-MAKING}

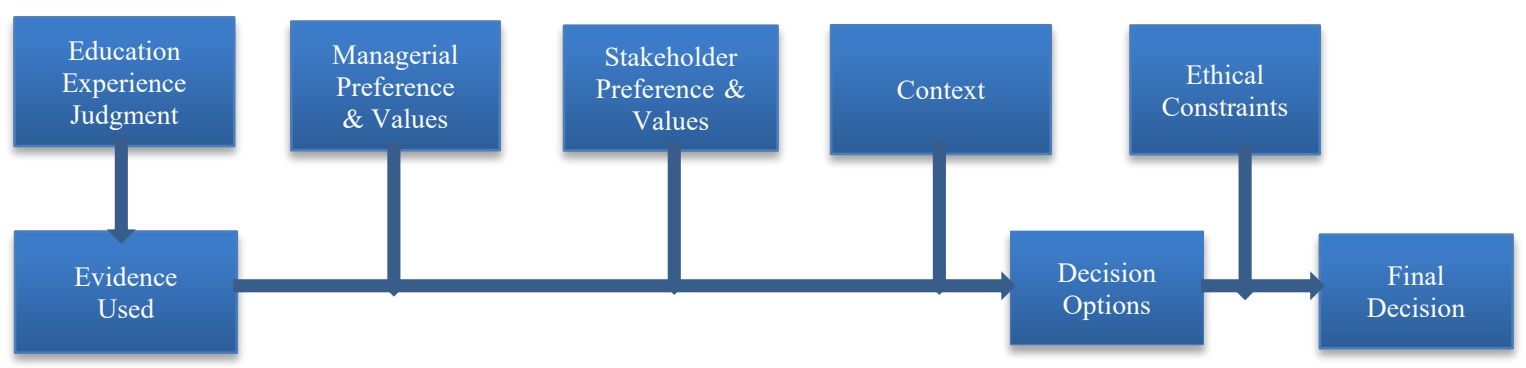

(Baba and HakemZadeh, 2012) 


\section{Theory of Stakeholder Salience}

The theory of stakeholder salience, developed by Mitchell et al. (1997), proposes that not all stakeholder groups will be able to have their preferences and values realized. That is, the more important stakeholder groups will command management's attention because of the very real consequences that may result if their claims are ignored. The theory answers the following two questions: 1) Who are the stakeholders? 2) Under what conditions will a manager pay more attention to one group of stakeholders versus another group? Mitchell et al. (1997) extracted concepts from several literatures (agency, behavioural, ecological, institutional, resource dependence and transaction cost theories of the firm) and identified three attributes power, legitimacy and urgency - to develop a typology of stakeholders. The typology was then used to predict the likely level of managerial attention each group would receive. It is important to note the dynamic nature of the model in that stakeholder groups may acquire or lose an attribute, thus increasing or decreasing their level of salience to an organization.

The theory posits that a stakeholder group has power if it has, or can gain access to, coercive, utilitarian or normative means to impose its will on an organization. Coercive power is based on the physical resources of force, violence or restraint. Utilitarian power is the use of resources, material or financial, for control purposes. Normative power is the use of non-physical resources such prestige and esteem for control purposes. Legitimacy, the second attribute, is based on Suchman's (1995) definition of legitimacy as a perception that the actions of an entity are desirable, proper or appropriate. It was thus argued that managers should pay attention to stakeholder groups whose claims are legitimate. The third attribute is urgency and the theory proposes that managers should pay attention to stakeholders whose claims are urgent because paying attention to stakeholder issues in a time sensitive manner has long been a topic of interest to crisis management scholars. Thus, as presented in Figure 2, stakeholders may possess one, two or three attributes, resulting in seven possible stakeholder groups.

The theory predicts that stakeholders will receive different levels of managerial attention depending on the number of attributes they possess. Latent stakeholders, who possess one attribute, are viewed as having low salience. They are categorized as dormant, discretionary or demanding stakeholders and will likely receive little or no managerial attention. Expectant stakeholders are considered to be moderately salient as they possess two of the three attributes. Depending on the combination of attributes, expectant stakeholders are considered dominant, dependent or dangerous. If stakeholders possess all three attributes they are considered to be highly salient and can expect to receive management's undivided attention. A summary of stakeholder types, salience and characteristics is presented in Table 1.

FIGURE 2

\section{STAKEHOLDER TYPOLOGY}

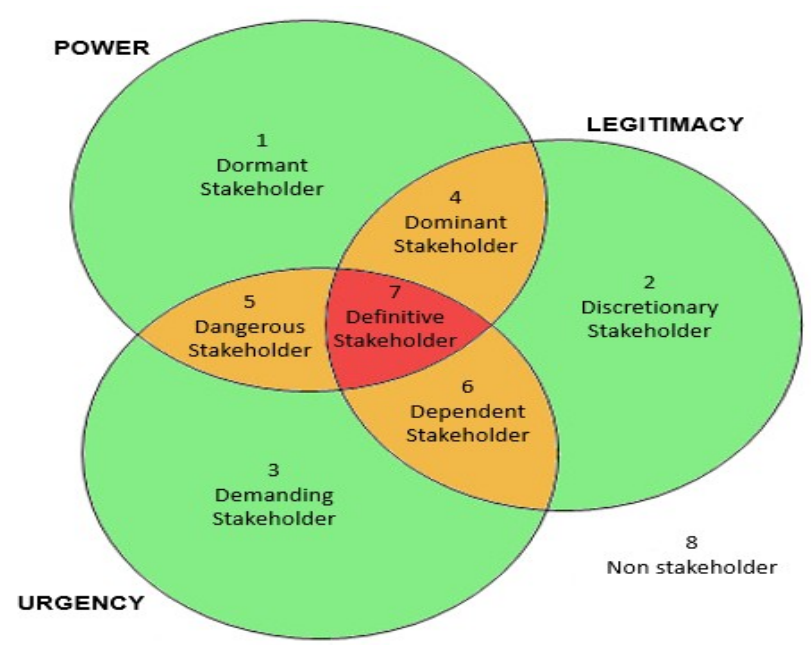

(Mitchell et al. (1997) 
TABLE 1

STAKEHOLDER TYPES, SALIENCE AND CHARACTERISTICS

\begin{tabular}{|c|c|c|c|c|}
\hline Type & Sub group & Attribute(s) & Salience & Characteristics \\
\hline \multirow[t]{3}{*}{ Latent (1 attribute) } & Dormant & Power & Low & $\begin{array}{l}\text { This group has the power to } \\
\text { impose their views on the } \\
\text { organization but lacks the } \\
\text { legitimacy or urgency to do so, so } \\
\text { its power remains unused. No } \\
\text { pressure for managerial attention, } \\
\text { but managers should be cognizant } \\
\text { of the possibility of higher } \\
\text { salience if a second attribute is } \\
\text { acquired. }\end{array}$ \\
\hline & Discretionary & Legitimacy & Low & $\begin{array}{l}\text { No pressure for managerial } \\
\text { attention, but managers may } \\
\text { engage with this group for other } \\
\text { reasons. Examples include } \\
\text { beneficiaries of charitable } \\
\text { donations. }\end{array}$ \\
\hline & Demanding & Urgency & Low & $\begin{array}{l}\text { Viewed as irksome but not } \\
\text { dangerous. Examples include } \\
\text { serial complainers, individuals } \\
\text { with unjustified grudges or low } \\
\text { return customers. }\end{array}$ \\
\hline $\begin{array}{l}\text { Expectant (2 } \\
\text { attributes) }\end{array}$ & Dominant & $\begin{array}{l}\text { Power } \\
\text { Legitimacy }\end{array}$ & Moderate & $\begin{array}{l}\text { Managerial attention for this } \\
\text { group is likely as they form the } \\
\text { dominant coalition. }\end{array}$ \\
\hline \multirow[t]{2}{*}{$\begin{array}{l}\text { Overall, managers see } \\
\text { moderately salient } \\
\text { stakeholders as } \\
\text { "expecting something." } \\
\text { Likely higher level of } \\
\text { engagement with these } \\
\text { stakeholders. }\end{array}$} & Dependent & $\begin{array}{l}\text { Legitimacy } \\
\text { Urgency }\end{array}$ & Moderate & $\begin{array}{l}\text { Managerial attention is likely if } \\
\text { this group relies on and obtains } \\
\text { the support of powerful } \\
\text { stakeholders. This group depends } \\
\text { on the support of powerful } \\
\text { stakeholders or the benevolence } \\
\text { of management to satisfy their } \\
\text { claims. }\end{array}$ \\
\hline & Dangerous & $\begin{array}{l}\text { Power } \\
\text { Urgency }\end{array}$ & Moderate & $\begin{array}{l}\text { Stakeholders who lack legitimacy } \\
\text { will be coercive and possibly } \\
\text { violent. Examples include wildcat } \\
\text { strikes, employee sabotage and } \\
\text { terrorism. }\end{array}$ \\
\hline
\end{tabular}




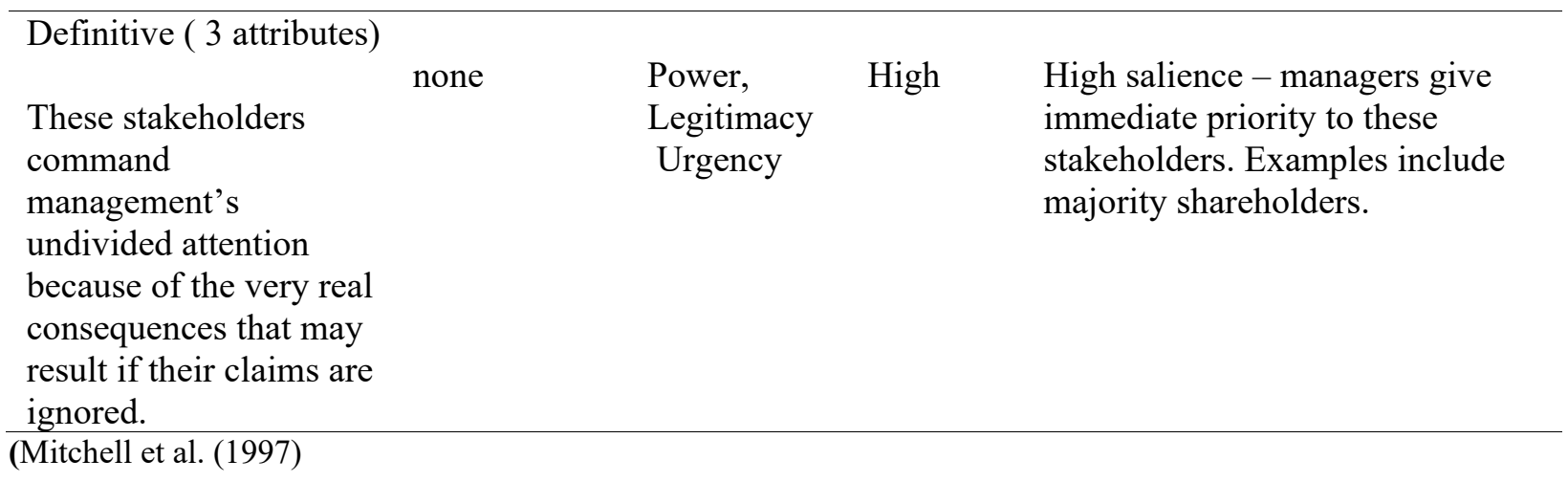

\section{LITERATURE REVIEW}

\section{Performance Management}

Although PM systems can de designed in a number of ways, they are essentially systems and philosophies that include a shared vision, teamwork, training, and incentives that are linked to performance measurement (Lebas, 1995). In turn, performance measurement is defined as a set of metrics that quantifies the efficiency and effectiveness of actions and are designed to support PM (Bourne et al., 2003). PI, also referred to as key performance indicators, is the result of performance measurement. More specifically, PI is defined as a systematic collection of data that is self-produced by the organization and reported in a quantitative, aggregated form (Hatry, 2006; Van Dooren et al., 2015).

Agency theory provides the foundation to explain why PM systems are implemented. The theory is based on the premise that principals and agents frequently have different preferences and may exploit information asymmetry to dodge their responsibilities or pursue actions that are in their own self-interest (Heinrich \& Marschke, 2010).

\section{Performance Information Use}

What does PI use mean? Most studies that measure PI use tend not to conceptualise what PI use means (Moynihan et al., 2012a). However, those studies that do, tend to conceptualise PI use in different ways. For example, PI use has been defined as a type of extra role behavior that requires additional effort on the part of the employee (Kroll \& Vogel, 2014). Similarly, Moynihan and Pandey (2010) conceptualized PI use as an organizational behavior that is influenced by individual job, organizational, and environmental circumstances. PI use can also be defined as actions to monitor or improve internal operations, to showcase performance, to give account, or to compare and benchmark (Hammerschmid et.al., 2013, Henri, 2006). PI use has also been viewed as a learning activity, which is mostly concerned with future improvements and with steering and controlling (Van Dooren et al., 2015). Moynihan et al. (2012a) proposed four ways PI can be used: purposeful, perverse, political, and passive. Purposeful use includes using PI to make strategic decisions, establish priorities, innovate, and solve problems. PI is used perversely if it is used in ways that are contrary to the goals of PM. PI can also be used in a political manner, for example, to argue for the legitimacy of a program or to make a case for resources. PI is used passively when the minimum is done in order to comply with various requirements. Although in many instances purposeful use is not specifically mentioned, a large majority of studies have examined the purposeful use of PI due to the performance movement's identification with values such as improved decision-making and efficiency, both of which imply purposeful use (Hatry, 2006; Radin, 2006).

\section{Variables Influencing PI Use}

There is a growing body of research that has identified the following variables as having a positive influence on PI use in the public sector: goal clarity; leadership support; organizational culture; organizational support; positive attitude towards PM; level of public service motivation; quality of PM system; and stakeholder support for PM. 
Goal clarity is said to exist when employees clearly understand the mission, vision, goals and strategic plans of the organization. When goal clarity is present studies have shown that PI use increases at a significant level (Moynihan \& Landuyt, 2009: Moynihan et al., 2012a). Leadership support is also a significant predictor of PI use and is demonstrated by enthusiasm for PM (Ho, 2006), the willingness to self-evaluate (Ammons \& Rivenbark, 2008; Boyne et al., 2004), a credible commitment to achieving results (Dull, 2009), the allocation of resources to PM, and leadership attention and involvement (Askim et al., 2008; Dull, 2009; Ho, 2006; Melkers \& Willoughby, 2005; Moynihan \& Ingraham, 2004). Organizational culture also matters for PI use. Cultures that accept PM are more likely to use PI for decision-making than those that are skeptical of, or opposed to, such systems (Taylor, 2011). Moynihan et al. (2012a) established a significant relationship between a developmental culture and PI use, whereas Taylor (2011) and Saliterer and Korac (2013) found that rational cultures are important predictors of PI use. PI use also increases when organizations offer managers the opportunity and discretion to experiment and actually use PI (Johansson \& Siverbo, 2009; Moynihan \& Landuyt, 2009; Moynihan \& Pandey, 2010). Organizational support also leads to increased PI use and is support, other than leadership and stakeholder support, that facilitates PI use. Examples include providing learning opportunities and professional development activities that allow employees to hone their skills in using and interpreting PI. Learning forums have been identified as a type of organizational support; these include activities such as strategic planning routines, after-action reviews, benchmarking processes, or other routines in which managers actively engage in the regular examination of performance data with peers and supervisors. Two studies (Moynihan \& Lavertu, 2012; Moynihan \& Landuyt, 2009) showed that learning forums significantly support organizational learning. Resources are another way to provide organizational support. Julnes and Holzer (2001) found that if employees have access to publications and on-line services about PM, or are able to attend conferences and workshops on the topic, PI use increases significantly. PI use is also influenced by a positive attitude and is defined as a favorable disposition towards innovation, change and performance measures (Ho, 2006; Julnes \& Holzer, 2001) and a willingness to be compared to others (Ammons \& Rivenbark, 2008). Another variable that predicts PI use is public service motivation (PSM), which is defined as beliefs, values and attributes that go beyond self-interest and organizational interest to encourage employees to do good for others and contribute to the well-being of society (Kroll \& Vogel, 2014). Several studies have identified the quality PM systems as important factor in PI use. Quality systems include specific characteristics of the PI itself, human expertise, and adequate technical and information systems. When PI is viewed as useful (Taylor, 2009), relevant and timely (Dull, 2009, Moynihan \& Landuyt, 2009) managers are more inclined to use it. As well, when higher-order metrics are used (efficiency versus input measures) (Ammons \& Rivenbark (2008), when PI is derived from goals and used to track performance (Taylor, 2009) easy to understand and measures what it is supposed to measure (Taylor, 2011), PI use increases significantly. Human expertise is also an important precursor to PI use. Employees who can relate outputs to program operations, develop outcome measures, compare actual results with program goals, analyze and compare performance data exhibit significantly higher levels of PI use (Berman \& Wang, 2000). Effective information systems, in which the right information gets to the right people at the right time, strongly and positively influence PI use (Berman \& Wang, 2000; Moynihan \& Landuyt, 2009). Several studies have shown that adequate stakeholder support and involvement is a key factor in integrating PI with decision-making. Berman and Wang (2000) showed that when department heads, managers, supervisors, and employees support PM, there is a significant increase in PI use and suggested that buy-in from lower-level managers, in particular, is important because managers can sabotage performance enhancement initiatives by deliberately dragging out the process. Involvement is as important as support. When managers and lower-level employees are involved in the development of performance measures that are derived from goals, PI use increases (Boyne et al.,2004; Taylor, 2009)) Likewise, Folz et al. (2009) discovered that buy-in from internal administrative and supervisory personnel most affects whether CEOs believe that PM has been beneficial to their organization. As well, when external stakeholders support PM there is a significant increase in PI use (Berman \& Wang, 2000; Julnes \& Holzer, 2001). 


\section{Stakeholder Theory}

Stakeholder theory defines stakeholders as any person or group that can affect, or be affected by, an organization (Freeman, 2010). The core idea of this theory is that owners/shareholders are not the only stakeholders in an organization, and organizations that manage their stakeholder relationships effectively will survive longer and perform better than organizations that do not.

There has been considerable debate about which stakeholder groups should prioritized. When stakeholder theory was first introduced it was considered to be opposed to the shareholder view but since then the discussion has evolved and now recognizes that stakeholders and shareholders are not competing objectives but mutually beneficial ones (Berman et al., 1999). One approach involves classifying stakeholders, determining their importance and establishing consensual relationships with those that are the most important. Indeed, most organizations still tend to focus their attention on known, salient, or powerful groups to protect their advantages in existing businesses (Hart \& Sharma, 2004). An alternative approach views stakeholder management as an act of balancing the needs of multiple constituents, not only the primary or powerful stakeholders. Hart and Sharma (2004) expanded this concept and suggested that in order to manage disruptive change and access knowledge to generate competitive imagination organizations may want to look beyond established stakeholder networks to fringe stakeholders.

\section{THE STUDY}

\section{Data Collection, Sampling Technique and Response Rate}

The data used in this study is from a larger study on performance management in the higher education sector (see Chan, 2018). Invitations to participate in the study were sent to all 71 public, nondenominational, English-speaking Canadian universities. Of these, 28 universities agreed to participate, 7 declined, and 36 did not respond. To obtain deeper insights, a purposive sampling technique was used, which selects respondents based on specific purposes associated with answering research questions (Teddlie \& Yu, 2007). This technique is often used to identify and select information-rich participants for the most effective use of limited resources and provides greater in-depth findings than other probability sampling methods (Cohen et.al., 2011). As the goal in this study was to recruit university administrators who would likely have experience with using PI, individuals occupying positions at the dean level or above were selected. The survey was sent to 425 potential respondents, one to each senior administrator (dean level and above) of the 28 universities, which represents an average of approximately 15 senior administrators per institution. A total of 101 surveys were completed, of which 69 were usable, yielding a response rate of 16.2 percent.

\section{Variables, Measurement and Data Analysis}

The independent variable, PI use, was measured using an existing survey developed by Henri (2006). The survey items measured, on a seven-point scale (1=high use), PI use in four areas: monitoring, attention focusing, strategic decision-making and legitimisation. Cronbach's alpha for each construct exceeded the recommended cut-off point of .70. Appendix 1 contains the survey used to measure PI use.

As it was not practical to measure the perceived salience of all stakeholders, respondents were asked to assess the salience of the following three internal groups: academics; students; and staff. These three dependent variables were measured using an existing instrument (on a seven-point scale, $1=$ high salience) developed by Agle et al. (1999) to test the theory of stakeholder salience. The wording was slightly modified for the higher education sector. The Cronbach's alpha also exceeded the recommended cut-off point of .70. Appendix 2 contains the survey used to measure perceived stakeholder salience.

The surveys were then pilot tested and some minor adjustments were made. The data analysis techniques included descriptive statistics, correlation, ANOVA and multiple linear regression (enter method) using the SPSS software package. 


\section{RESULTS}

The results of the Pearson correlation are presented in Table 2. The correlation between PI use and perceived salience of staff is significant at $\mathrm{p}=.05$.

TABLE 2

PEARSON CORRELATION

\begin{tabular}{|l|l|c|c|c|c|}
\hline & & PI use & $\begin{array}{c}\text { Perceived } \\
\text { salience } \\
\text { Academics }\end{array}$ & $\begin{array}{c}\text { Perceived } \\
\text { salience } \\
\text { Students }\end{array}$ & $\begin{array}{c}\text { Perceived } \\
\text { salience } \\
\text { Staff }\end{array}$ \\
\hline Pearson Correlation & PI use & 1 & & & \\
\hline & Perceived salience - Academics & .183 & 1 & & \\
\hline & Perceived salience - Students & .086 & .384 & 1 & \\
\hline & Perceived salience - Staff & .258 & .277 & .320 & 1 \\
\hline Sig. (1-tailed) & PI use & & .066 & .241 & $.016^{*}$ \\
\hline & Perceived salience - Academics & .066 & & $.001^{*}$ & $.011^{*}$ \\
\hline & Perceived salience - Students & .241 & $.001^{*}$ & & $.004^{*}$ \\
\hline & Perceived salience - Staff & $.016^{*}$ & $.011^{*}$ & $.004^{*}$ & \\
\hline
\end{tabular}

* significant at $\mathrm{p}=.05$

Descriptive statistics, shown in Table 3, reveal a mean of 2.6550 for PI use $(1=$ high use $)$ and a standard deviation of .56957. Of the three stakeholder groups, academics have the highest perceived salience with a mean of $2.5833(1=$ high salience $)$ and staff have the lowest perceived salience with a mean of 3.5091.

TABLE 3

DESCRIPTIVE STATISTICS PERCEIVED STAKEHOLDER SALIENCE

\begin{tabular}{|l|c|c|c|c|c|}
\hline & N & Minimum & Maximum & Mean & $\begin{array}{c}\text { Std. } \\
\text { Deviation }\end{array}$ \\
\hline PI Use & 69 & 1.00 & 3.58 & 2.6550 & .56957 \\
\hline Perceived salience - Academics & 69 & 1.38 & 4.13 & 2.5833 & .63864 \\
\hline Perceived salience - Students & 69 & 1.25 & 5.00 & 3.0471 & .83498 \\
\hline Perceived salience - Staff & 69 & 1.00 & 5.63 & 3.5091 & .90731 \\
\hline
\end{tabular}

The results of the one-way repeated-measures ANOVA indicate a significant difference between the three means for perceived stakeholder salience (Wilks' Lambda $(\mathrm{F}(2,67)=33.713, \mathrm{p}=.000)$. As a result of this finding, post-hoc tests were conducted to determine which means were different. Table 4 shows the results of the post-hoc tests, which indicate a significant difference between the perceived salience of academics and that of students and staff. There is also a significant difference between the perceived salience of students and that of staff. 
TABLE 4

POST-HOC RESULTS: PERCEIVED STAKEHOLDER SALIENCE

\begin{tabular}{|l|l|r|r|r|}
\hline Perceived Salience of & Perceived Salience of & Mean Difference & Std. Error & Sig.** \\
\hline Academics & Students & $-.454^{*}$ & .100 & .000 \\
\hline & Staff & $-.926^{*}$ & .115 & .000 \\
\hline & & & & \\
\hline Students & Academics & $.464^{*}$ & .100 & .000 \\
\hline & Staff & $-.462^{*}$ & .122 & .001 \\
\hline Staff & & & & \\
\hline & Academics & $.926^{*}$ & .115 & .000 \\
\hline
\end{tabular}

*the mean difference is significant at the $\mathrm{p}=.05$

$* *$ adjustment for multiple comparisons: Bonferroni

Table 5 provides descriptive statistics on the three components that comprise the perceived salience construct. The results of the ANOVA and post-hoc tests, comparing the means of power, urgency and legitimacy are presented in Table 6. Academics are perceived to be more powerful than both students and staff, and students are perceived to be more powerful than staff. From an urgency perspective, there is a significant difference between academics and staff, and between students and staff. The only significant difference for perceived legitimacy is between academics and staff.

TABLE 5

DESCRIPTIVE STATISTICS: PERCEIVED POWER, URGENCY \& LEGITIMACY

\begin{tabular}{|l|c|c|c|c|c|}
\hline Stakeholder Group & $\mathbf{N}$ & $\begin{array}{c}\text { Mean } \\
\text { Perceived } \\
\text { Power } \\
\mathbf{( 3 ~ i t e m s )}\end{array}$ & $\begin{array}{c}\text { Mean } \\
\text { Perceived } \\
\text { Urgency } \\
\mathbf{( 3 ~ i t e m s )}\end{array}$ & $\begin{array}{c}\text { Mean } \\
\text { Perceived } \\
\text { Legitimacy } \\
\mathbf{( 2} \text { items })\end{array}$ & $\begin{array}{c}\text { Mean } \\
\text { Perceived } \\
\text { Salience } \\
\text { ( 8 items) }\end{array}$ \\
\hline Academics & 69 & 1.9469 & 2.5749 & 3.5507 & 2.5833 \\
\hline Students & 69 & 2.6908 & 2.9469 & 3.7319 & 3.0471 \\
\hline Staff & 69 & 3.0870 & 3.6377 & 3.9493 & 3.5091 \\
\hline
\end{tabular}

TABLE 6

ANOVA RESULTS

PERCEIVED POWER, URGENCY \& LEGITIMACY

\begin{tabular}{|l|l|l|}
\hline Comparison of Means & \multicolumn{1}{|c|}{$\begin{array}{c}\text { Wilks Lambda } \\
\text { F value and sig. }\end{array}$} & \multicolumn{1}{|c|}{ Post-hoc results } \\
\hline Power & & \\
\hline $\begin{array}{l}\text { Perceived power - } \\
\text { academics }\end{array}$ & & \\
\hline Perceived power - students & $\begin{array}{l}\mathrm{F}(2,67)=40.125, \mathrm{p}= \\
.000\end{array}$ & $\begin{array}{l}\text { Each mean is significantly different from the } \\
\text { other }\end{array}$ \\
\hline Perceived power - staff & & \\
\hline
\end{tabular}




\begin{tabular}{|l|l|l|}
\hline Urgency & & \\
\hline $\begin{array}{l}\text { Perceived urgency - } \\
\text { academics }\end{array}$ & $\begin{array}{l}\text { Significant difference between academics and } \\
\text { staff }\end{array}$ \\
\hline Perceived urgency - students & $\mathrm{F}(2,67)=21.205, \mathrm{p}=$ & $\begin{array}{l}\text { Significant difference between students and } \\
\text { staff }\end{array}$ \\
\hline Perceived urgency - staff & 000 & $\begin{array}{l}\text { No significant difference between academics } \\
\text { and students }\end{array}$ \\
\hline Legitimacy & & $\begin{array}{l}\text { Significant difference between academics and } \\
\text { staff }\end{array}$ \\
\hline $\begin{array}{l}\text { Perceived legitimacy - } \\
\text { academics }\end{array}$ & $\begin{array}{l}\text { No significant difference between academics } \\
\text { and students }\end{array}$ \\
\hline $\begin{array}{l}\text { Perceived legitimacy - } \\
\text { academics }\end{array}$ & .003 & $\begin{array}{l}\text { No significant difference between students and } \\
\text { staff }\end{array}$ \\
\hline $\begin{array}{l}\text { Perceived legitimacy - } \\
\text { academics }\end{array}$ & & \\
\hline & & \\
\hline
\end{tabular}

Table 7 presents the regression results. The initial model included all three predictor variables, which produced an insignificant result. After several iterations, Model 5 produced a significant result, with $\mathrm{F}$ $(1,67)=4.791, \mathrm{p}=.032$.

TABLE 7 REGRESSION RESULTS

\begin{tabular}{|c|c|c|c|c|c|}
\hline & Model 1 & Model 2 & Model 3 & Model 4 & Model 5 \\
\hline Independent Variables & $\begin{array}{c}\text { Academics } \\
\text { Students } \\
\text { Staff }\end{array}$ & $\begin{array}{c}\text { Academics } \\
\text { Students }\end{array}$ & Academics & Students & Staff \\
\hline Constant -PI Use & $\begin{array}{l}1.915 \\
(.359)\end{array}$ & $\begin{array}{l}2.211 \\
(.327)\end{array}$ & $\begin{array}{l}2.233 \\
(.285)\end{array}$ & $\begin{array}{l}2.476 \\
(.262)\end{array}$ & $\begin{array}{l}2.086 \\
(.268)\end{array}$ \\
\hline Perceived Salience - Academics & $\begin{array}{l}.119 \\
(.117)\end{array}$ & $\begin{array}{c}.157 \\
(.117) \\
\end{array}$ & $\begin{array}{l}.163 \\
(.107)\end{array}$ & & \\
\hline Perceived Salience - Students & $\begin{array}{l}-.027 \\
(.090)\end{array}$ & $\begin{array}{c}.013 \\
(.089) \\
\end{array}$ & & $\begin{array}{c}.059 \\
(.083)\end{array}$ & \\
\hline Perceived Salience - Staff & $\begin{array}{c}.147 \\
(.080)\end{array}$ & . & & & $\begin{array}{l}.162 * \\
(.075)\end{array}$ \\
\hline R-squared & .081 & .034 & .034 & .007 & .067 \\
\hline Adjusted R-squared & .039 & .005 & .019 & -.007 & .053 \\
\hline
\end{tabular}

*significant at $\mathrm{p}=.05$

Standard errors are reported in parentheses.

\section{DISCUSSION}

The mean level of PI use is 2.6550, with 1 representing the highest use. Baba and HakemZadeh's (2012) conceptual theory of evidence-based decision-making (see Figure 1) can explain this high level of PI use. The theory proposes that context is one factor that influences whether evidence, or PI in this case, is 
incorporated into decision-options. Johns (2006) defined context as situational opportunities and constraints that affect the occurrence and meaning of organizational behaviour as well as functional relationships between variables. Indeed, the plight of many higher education institutions has been in the spotlight for a number of years. Increasing costs, large deficits and increased competition for students are just some of the many challenges universities are facing. Today, scrutiny of public sector organizations, including universities, continues in earnest. Demands from, for example, government, funding bodies, and taxpayers to demonstrate accountability are omnipresent (Kimberly \& Bouchikhi, 2016). One way to meet these accountability demands is to use PI to prepare budgets, reduce costs, inform decision-making, allocate resources, monitor operations and improve services, to name only a few.

The perceived salience of academics is consistent with their status as professionals, who are defined as those employees who possess the skills and knowledge designated by a professional body to control entry to the profession (Evetts \& Buchner-Jeziorska, 1997). They demand autonomy and control in their work and rather than be dominated by the organizations they work for, professionals expect to influence the strategic direction of the organization ( Mintzberg, 1980). Indeed, the manner in which many universities structured allows academics to have a say in setting the strategic direction of the organization. That is, principles of shared governance and bi-cameral systems, where the governing board shares responsibilities with the senate, put academics in the unique position to wield significant influence in many university matters. Academics rank highest on perceived power and lowest on the perceived legitimacy of their claims. However, the overall mean of 2.5833 for perceived salience is the highest of the three stakeholder groups and as a result academics would likely be classified as definitive stakeholders as per the typology in Figure 2. Thus, according to the theory of stakeholder salience, university administrators should give academics their undivided attention as well as immediate priority.

The perceived salience of students is also above average but below that of academics and above that of staff. Student tuition fees account for a large portion of university revenues. Thus, ensuring that students are satisfied and have an excellent experience has been a priority for many higher education institutions. As well, this coupled with the intense competition in recruiting students, especially international students who pay much higher tuition, has resulted in viewing students as important "customers". This may be particularly true of university administrators who are held accountable for recruiting and retention performance. As a result, students could be classified as either definitive or expectant stakeholders and would receive either high or likely managerial attention respectively.

Staff, sometimes referred to as general or support staff, is one stakeholder group that represents a large part of a university's infrastructure. They have traditionally been forgotten or ignored because the reputation of a university is made or lost on the actual or perceived quality of its research and teaching by academics. Of the three stakeholder groups staff has the lowest level of salience, which is just at the mid-way point of the scale. Staff do not fit the category of latent stakeholder as university administrators do not ignore this group altogether. Thus, staff may be considered expectant stakeholders and will likely receive some managerial attention. However this may be changing. Over the past few decades staff, a new category of university employees, now referred to as professional staff, is growing and they are securing a more critical space in the higher education sector. At senior levels, professional staff are no longer only in specialist roles such as human resources, information technology or facilities. Rather, they now occupy roles that were once reserved for senior academics such as vice-president - particularly if the portfolio has a student, international, fundraising, marketing or corporate focus.

The multiple regression results indicate that the only significant variable is the perceived salience of staff. The result that academics are perceived to be more salient than staff but have no influence on PI use is surprising. Based on this result, it would appear that the theory of stakeholder salience does not apply. Another explanation is that the theory does apply but there is a moderating variable that affects the relationship between PI use and perceived salience. This moderating variable could be proximity. That is, even though academics and students have a higher salience rating they are not as close to the everyday decision-making activities as staff. Research shows that the proximity among individuals in an organization can exert considerable influence on a variety of organizational outcomes ( Monge et al., 1985) and this may include the extent to which PI is used. Furthermore, the coefficient is positive - for a one unit increase in 
perceived salience of staff, PI use increases by.162. Again, this may be a reflection of professional staff having a positive influence on PI use.

\section{LIMITATIONS AND SUGGESTIONS FOR FUTURE RESEARCH}

There are several limitations to this research study. As with most surveys, respondents may have felt uncomfortable providing answers that would present them in an unfavourable manner. As a result, they may have mis-stated their use of PI and perceptions of stakeholder salience for each of the three groups. Another limitation is that all the respondents were from Canadian universities and therefore the results obtained in this study may not be applicable to other jurisdictions.

Future studies could measure the perceived salience of stakeholder groups other than the ones examined in this study such as governing boards and governments. Future research could also examine the impact of proximity to decision-making activities on PI use. It would also be interesting to examine the nature of academic salience. That is, academics have salience but where does this salience reside?

\section{CONCLUSION}

This study set out to investigate the relationship between PI use and the perceived salience of three stakeholder groups in the higher education sector. The study found a significant relationship between perceived salience of staff and the extent of PI use. However, this was not what was expected. It was expected that academics, with the highest level of perceived salience, would influence PI use. One explanation may be the presence of a moderating variable - proximity to the decision-making activities.

\section{ACKNOWLEDGEMENT}

This is to acknowledge no financial interest or benefit has arisen from the direct applications of this research study.

\section{REFERENCES}

Agle, B.R., Mitchell, R.K., \& Sonnenfeld, J.A. (1999). Who matters to CEOs? An investigation of stakeholder attributes and salience, corporate performance, and CEO values. Academy of Management Journal, 42(5), 507-525. doi: org/10.2307/256973

Alvesson, M., \& Spicer, A. (2016). (Un) Conditional Surrender? Why do Professionals Willingly Comply with Managerialism. Journal of Organizational Change Management, 29(1), 29-45. doi:10.1108/JOCM-11-2015-0221

Ammons, D.N., \& Rivenbark, W.C. (2008). Factors influencing the use of performance data to improve municipal services: Evidence from the North Carolina benchmarking project. Public Administration Review, 68(2), 304-318. doi:org/10.1111/j.1540-6210.2007.00774.x

Ashford, K. (2014). 5 Steps to Calculating your College R.O.I. Forbes. Retrieved from https://www.forbes.com/sites/learnvest/2014/08/29/5-steps-to-calculating-your-college-r-o$\mathrm{i} / \# 556835265485$

Askim, J., Johnsen, Å., \& Christophersen, K.A. (2008). Factors behind organizational learning from benchmarking: Experiences from Norwegian municipal benchmarking networks. Journal of Public Administration Research and Theory, 18(2), 297-320. doi:org/10.1093/jopart/mum012

Baba, V.V., \& HakemZadeh, F. (2012). Toward a theory of evidence based decision-making. Management Decision, 50(5), 832-867. doi:org/10.1108/00251741211227546

Berman, E., \& Wang, X. (2000). Performance measurement in US counties: Capacity for reform. Public Administration Review, 60(5), 409-420. doi:org/10.1111/0033-3352.00104 
Berman, S.L., Wicks, A.C., Kotha, S., \& Jones, T.M. (1999). Does stakeholder orientation matter? The relationship between stakeholder management models and firm financial performance. Academy of Management Journal, 42(5), 488-506. doi:org/10.1111/j.1540-6210.2007.00774.x

Birdsall, C. (2018). Performance Management in Public Higher Education: Unintended Consequences and the Implications of Organizational Diversity. Public Performance \& Management Review, 41(4), 669-695. doi:10.1080/15309576.2018.1481116

Blau, P.M. (1994). The organization of academic work (2nd ed.). New York, NY: Routledge.

Bourne, M., Neely, A., Mills, J., \& Platts, K. (2003). Implementing Performance Measurement Systems: A Literature Review. International Journal of Business Performance Management, 5(1), 1-24. doi:10.1504/ijbpm.2003.002097

Boyne, G.A., Gould-Williams, J.S., Law, J., \& Walker, R.M. (2004). Toward the self-evaluating organization? An empirical test of the Wildavsky model. Public Administration Review, 64(4), 463-473. doi:org/10.1111/j.1540-6210.2004.00392.x

Buchner-Jeziorska, A., \& Evetts, J. (1997). Regulating professionals: the Polish example. International Sociology, 12(1), 61-72. doi.org/10.1177/026858097012001004

Cain, J., Romanelli, F., \& Smith, K. (2012). Academic entitlement in pharmacy education. American Journal of Pharmaceutical Education, 76(10), 189. doi: org/10.5688/ajpe7610189

CAUT. (2020). The rise of performance-based funding. Retrieved from https://www.caut.ca/bulletin/2020/04/rise-performance-based-funding

Chan, G. (2018). Performance Information Use in the Canadian Higher Education Sector. Doctoral diss., Athabasca University.

Cohen, L., Manion, L., \& Morrison, K. (2011). Research Methods in Education (7th ed.). New York, NY: Routledge.

Craig, R., Amernic, J., \& Tourish, D. (2014). Perverse Audit Culture and Accountability of the Modern Public University. Financial Accountability \& Management, 30(1), 1-24. doi:10.1111/faam.12025

Dull, M. (2009). Results-model reform leadership: Questions of credible commitment. Journal of Public Administration Research and Theory, 19(2), 255-284. doi: org/10.1093/jopart/mum043

Folz, D.H., Abdelrazek, R., \& Chung, Y. (2009). The adoption, use, and impacts of performance measures in medium-size cities. Public Performance \& Management Review, 33(1), 63-87. doi: org/10.2753/PMR1530-9576330103

Freeman, R.E. (2010). Strategic management: A stakeholder approach. Cambridge University Press.

Gordon, G., \& Whitchurch, C. (2007). Managing human resources in higher education: The implications of a diversifying workforce. Higher Education Management and Policy, 19(2), 1-21. doi:org/10.1111/j.1540-6210.2007.00774.x

Hammerschmid, G., Van de Walle, S.G.J., \& Štimac, V. (2013). Internal and External Use of Performance Information in Public Organisations: Results from an International Executive Survey. Public Money and Management, 33(4), 1-16. doi:10.1080/09540962.2013.799803

Hart, S.L., \& Sharma, S. (2004). Engaging fringe stakeholders for competitive imagination. Academy of Management Perspectives, 18(1), 7-18. doi:org/10.1111/j.1540-6210.2007.00774.x

Hatry, H.P. (2006). Performance Measurement: Getting Results. Washington, DC: The Urban Institute.

Heinrich, C.J., \& Marschke, G. (2010). Incentives and their Dynamics in Public Sector Performance Management Systems. Journal of Policy Analysis and Management, 29(1), 183-208. doi:10.1002/pam.20484

Henri, J.F. (2006). Organizational Culture and Performance Measurement Systems. Accounting, Organizations and Society, 31(1), 77-103. doi:10.1016/j.aos.2004.10.003

Ho, A.T.K. (2006). Accounting for the value of performance measurement from the perspective of Midwestern mayors. Journal of Public Administration Research and Theory, 16(2), 217-237. doi:org/10.1093/jopart/mui046 
Johansson, T., \& Siverbo, S. (2009). Explaining the utilization of relative performance evaluation in local government: A multi-theoretical study using data from Sweden. Financial Accountability and Management, 25(2), 197-224. doi:org/10.1111/j.1540-6210.2007.00774.x

Johns, G. (2006). The essential impact of context on organizational behavior. Academy of Management Review, 31(2), 386-408. doi: org/10.5465/amr.2006.20208687

Julnes, P.D.L., \& Holzer, M. (2001). Promoting the utilization of performance measures in public organizations: An empirical study of factors affecting adoption and implementation. Public Administration Review, 61(6), 693-708. doi:org/10.1111/0033-3352.00140

Kairuz, T., Andriés, L., Nickloes, T., \& Truter, I. (2016). Consequences of KPIs and Performance Management in Higher Education. International Journal of Educational Management, 30(6), 881-893. doi:10.1108/ijem-05-2015-0067

Kalfa, S., Wilkinson, A., \& Gollan, J.P. (2018). The Academic Game: Compliance and Resistance in Universities. Work, Employment and Society, 32(2), 274-291. doi:10.1177/0950017017695043

Kallio, K.M., Kallio, T.J., Tienari, J., \& Hyvönen, T. (2016). Ethos at Stake: Performance Management and Academic Work in Universities. Human Relations, 69(3), 685-709. doi:10.1177/0018726715596802

Kenny, J. (2017). Academic Work and Performativity. Higher Education, 74(5), 897-913. doi:10.1007/s10734-016-0084-y

Kimberly, J.R., \& Bouchikhi, H. (2016). Disruption on steroids: Sea change in the worlds of higher education in general and business education in particular. Journal of Leadership \& Organizational Studies, 23(1), 5-12.

Kroll, A., \& Vogel, D. (2014). The PSM-Leadership Fit: A Model of Performance Information Use. Public Administration, 92(4), 974-991. doi:10.1111/padm.12014

Lebas, M.J. (1995). Performance Measurement and Performance Management. International Journal of Production Economics, 41(1), 23-35. doi:org/10.1111/j.1540-6210.2007.00774.x

Loi, K.I., \& Pearce, P.L. (2012). Powerful stakeholders' views of entertainment in Macao's future. Journal of Business Research, 65(1), 4-12. doi:org/10.1111/j.1540-6210.2007.00774.x

Maple, C. (2013). Return on Investment and Why it Matter for Higher Education. Huffington Post. Retrieved from https://www.huffingtonpost.com/chris-maples/return-on-investment-roib_3626205.html

Melkers, J., \& Willoughby, K. (2005). Models of performance-measurement use in local governments: Understanding budgeting, communication, and lasting effects. Public Administration Review, 65(2), 180-190. doi:org/10.1111/j.1540-6210.2005.00443.x

Mintzberg, H. (1980). Structure in 5's: A Synthesis of the Research on Organization Design. Management Science, 26(3), 322-341.

Mitchell, R.K., Agle, B.R., \& Wood, D.J. (1997). Toward a theory of stakeholder identification and salience: Defining the principle of who and what really counts. Academy of Management Review, 22(4), 853-886. doi:org/10.1111/j.1540-6210.2005.00443.x

Monge, P.R., Rothman, L.W., Eisenberg, E.M., Miller, K.I., \& Kirste, K.K. (1985). The dynamics of organizational proximity. Management Science, 31(9), 1129-1141. doi:org/10.1287/mnsc.31.9.1129

Moynihan, D.P., \& Ingraham, P.W. (2004). Integrative Leadership in the Public Sector: A Model of Performance-Information Use. Administration \& Society, 36(4), 427-453. doi: $10.1177 / 0095399704266748$

Moynihan, D.P., \& Landuyt, N. (2009). How do Public Organizations Learn? Bridging Cultural and Structural Perspectives. Public Administration Review, 69(6), 1097-1105. doi:10.1111/j.15406210.2009.02067.x

Moynihan, D.P., \& Lavertu, S. (2012). Does Involvement in Performance Management Routines Encourage Performance Information Use? Evaluating GPRA and PART. Public Administration Review, 72(4), 592-602. doi:10.1111/j.1540-6210.2011.02539.x 
Moynihan, D.P., \& Pandey, S.K. (2010). The big question for performance management: Why do managers use performance information? Journal of Public Administration Research and Theory, 20(4), 849-866. doi:org/10.1093/jopart/muq004

Moynihan, D.P., Pandey, S.K., \& Wright, B.E. (2012a). Setting the Table: How Transformational Leadership Fosters Performance Information Use. Journal of Public Administration Research and Theory, 22(1), 143-164. doi:10.1093/jopart/mur024

Moynihan, D.P., Pandey, S.K., \& Wright, B.E. (2012b). Prosocial values and performance management theory: Linking perceived social impact and performance information use. Governance, 25(3), 463-483. doi:org/10.1111/j.1468-0491.2012.01583.x

Pollitt, C. (2002). The new public management in international perspective. New Public Management: Current Trends and Future Prospects. Retrieved from https://edisciplinas.usp.br/pluginfile.php/4626057/mod_resource/content/1/Book\%20New_Public Management_Current_Trends\%20\%281\%29.pdf\#page $=287$

Pollitt, C. (2006). Performance management in practice: A comparative study of executive agencies. Journal of Public Administration Research and Theory, 16(1), 25-44. doi:org/10.1093/jopart/mui045

Radin, B. (2006). Challenging the Performance Movement: Accountability, Complexity, and Democratic Values. Washington, DC: Georgetown University Press.

Saliterer, I., \& Korac, S. (2013). Performance Information Use by Politicians and Public Managers for Internal Control and External Accountability Purposes. Critical Perspectives on Accounting, 24(7), 502-517. doi:10.1016/j.cpa.2013.08.001

Schito, J., Jullier, J., \& Raubal, M. (2019). A framework for integrating stakeholder preferences when deciding on power transmission line corridors. EURO J Decis Process, 7, 159-195. doi:org/10.1007/s40070-019-00100-w

Schneijderberg, C., \& Merkator, N. (2013). The new higher education professionals. In The academic profession in Europe: New tasks and new challenges (pp. 53-92). Springer, Dordrecht. doi:org/10.1007/978-94-007-4614-5_5

Speklé, R.F., \& Verbeeten, F.H. (2014). The use of performance measurement systems in the public sector: Effects on performance. Management Accounting Research, 25(2), 131-146. doi:org/10.1016/j.mar.2013.07.004

Suchman, M.C. (1995). Managing legitimacy: Strategic and institutional approaches. Academy of Management Review, 20(3), 571-610. doi:org/10.1016/j.mar.2013.07.004

Taylor, J. (2009). Strengthening the Link Between Performance Measurement and Decision-Making. Public Administration, 87(4), 853-871. doi:10.1111/j.1467-9299.2009.01788.x

Taylor, J. (2011) Factors Influencing the Use of Performance Information for Decision Making in Australian State Agencies. Public Administration, 89(4), 1316-1334. doi:10.1111/j.14679299.2011.02008.x

Teddlie, C., \& Yu, F. (2007). Mixed Methods Sampling: A Typology with Examples. Journal of Mixed Methods Research, 1(1), 77-100. doi:10.1177/1558689806292430

Thompson, B.S., \& Friess, D.A. (2019). Stakeholder preferences for payments for ecosystem services (PES) versus other environmental management approaches for mangrove forests. Journal of Environmental Management, 233, 636-648. doi:org/10.1016/j.mar.2013.07.004

Van Dooren, W., Bouckaert, W.G., \& Halligan, J. (2015). Performance Management in the Public Sector. London: Routledge.

Van Dooren, W.V., \& Wouter, V.D. (2008). Performance information in the public sector: How it is used. Houndmills, UK: Palgrave.

Yamane, T., \& Kaneko, S. (2021). Impact of raising awareness of Sustainable Development Goals: A survey experiment eliciting stakeholder preferences for corporate behavior. Journal of Cleaner Production, 285, 125291. doi:org/10.1016/j.mar.2013.07.004 
Yang, K., \& Hsieh, J.Y. (2007). Managerial effectiveness of government performance measurement:

Testing a middle-range model. Public Administration Review, 67(5), 861-879.

doi:org/10.1111/j.1540-6210.2007.00774.x

\section{APPENDIX 1: SURVEY USED TO MEASURE PI USE (HENRI 2006)}

\section{Definition of Performance Information}

Financial and non-financial information regularly compiled by an institution on the performance of activities, processes, services, products, departments, programs business units etc. that can be used by management in performing their jobs.

In the last six months I have used performance information to:

$(7=$ never, $6=$ rarely, $5=$ occasionally, $4=$ sometimes, $3=$ frequently, $2=$ usually, $1=$ every time $)$

Monitoring

1. Track progress towards goals

2. Review key measures

3. Monitor results

4. Compare outcomes to expectations

Attention-focusing

5. Tie my unit together

6. Develop a common vocabulary in my unit

7. Provide a common view of my unit

8. Enable discussions in meetings with superiors, subordinates and peers

9. Enable continual challenge and debate underlying results, assumptions and plans

10. Enable my unit to focus on critical success factors

11. To identify what problems my unit should be looking into

Strategic decision-making

12. Make strategic decisions once the need for a decision was identified and an immediate response was required

13. Make strategic decisions once the need for a decision was identified and an immediate response was NOT required

14. Make decisions when it was difficult to differentiate among plausible solutions to a problem because each had good arguments (i.e.: they could not be easily ranked)

15. Make decisions regarding an unstructured problem that had not been encountered before

16. To anticipate the future direction of my unit, as opposed to responding to an identifiable problem

17. Make a final decision on a strategic issue of major importance

Legitimization

18. Confirm my unit's understanding of the business

19. Justify decisions

20. Verify assumptions

21. Maintain perspectives

22. Support actions

23. Reinforce beliefs

24. Stay close to the business

25. Increase focus

26. Validate a point of view 


\section{APPENDIX 2: SURVEY USED TO MEASURE STAKEHOLDER SALIENCE}

\section{Definitions}

1. Stakeholders: Individuals or groups of individuals that can affect, or be affected by, an organization's actions, objectives and policies.

2. Stakeholder power is defined as a group/person possessing any one of the following three abilities:

- The ability to apply a high level of direct economic reward or punishment to obtain its will (e.g.: offering/withholding funds, resources, goods, services etc.)

- The ability to apply coercive or physical force to obtain its will (e.g.: guns, lockouts, sabotage, including access to legal processes that can invoke the use of physical force)

- The ability to positively or negatively influence the reputation or the prestige of an organization to obtain its will (e.g.: by going to the media)

For each stakeholder group please rate each statement based on your interaction with this group in the past six months

$(1=$ strongly agree, $7=$ strongly disagree $)$

1. The (academic, student, staff) stakeholder group had power (whether used or not)

2. The (academic, student, staff) stakeholder group had the power to enforce its claims, demands or desires (whether used or not)

3. The (academic, student, staff) stakeholder group had the ability to impact my unit/department (whether used or not)

4. The (academic, student, staff) stakeholder group actively pursued its claims, demands or desires

5. The (academic, student, staff) stakeholder group urgently communicated its claims, demands or desires

6. The (academic, student, staff) stakeholder group actively sought attention regarding its claims, demands or desires

7. The (academic, student, staff) claims, demands or desires of the (academic) stakeholder group were viewed as legitimate (proper or appropriate)

8. The claims, demands or desires of the(academic, student, staff) stakeholder group were not proper or appropriate (reverse coded) 